(научный руководитель - кандидат технических наук А. А. Беседа)

\author{
Луганский национальный университет имени Тараса Шевченко
}

\title{
ИССЛЕДОВАНИЕ ТЕХНОЛОГИЧЕСКИХ СВОЙСТВ ОБЪЕКТА СЕПАРАЦИИ И ФУНКЦИОНАЛЬНЫХ ВОЗМОЖНОСТЕЙ РАБОЧИХ ОРГАНОВ СЕПАРИРУЮЩИХ УСТРОЙСТВ
}

\section{Рецензент - доктор технических наук А. В. Чесноков}

\begin{abstract}
Робота присвячена дослідженню пристроїв для сепарації крупнозернистих сільськогосподарських матеріалів $і$ їх роботи в залежності від типу $і$ стану грунту. Розглянуто об'єкт сепарування, вивчено його фізико-механічні, технологічні властивості і основні закономірності, які впливають на якісні показники роботи сепаруючих пристроїв. Проведено аналіз пристроїв для вторинної сепарації, виявлено можливості їх використання за різного складу сипучого матеріалу, та зроблено висновок про напрям подальшого вивчення питання сепарації.
\end{abstract}

Ключові слова: трунт, технологічний процес, сепарація, фрикційні властивості, сипкий матеріал, домішки.

Постановка проблемы. Состояние почв непосредственно влияет на протекание технологического процесса сепарации, а в частности на показатели работоспособности сепарирующих устройств картофелеуборочных машин. Наибольшее влияние оказывают механический состав и влажность почвы [8].

Поэтому определение степени влияния состояния почвы на качественные показатели во время технологической операции сепарации и изучение возможностей устройств различных типов является актуальной задачей и требует более детального изучения.

Анализ последних исследований и публикаций по данной проблеме. В процессе создания эффективных сепарирующих систем картофелеуборочных машин отдельными учеными проводились исследования. Так, в работах Н. Н. Колчина исследованы условия работы, свойства культур и технологические процессы уборки, послеуборочной доработки и хранения картофеля [3]. В основу исследований Г. Д. Петрова положен поточный способ уборки картофеля и исследование комплекса машин для его реализации [6]. Вопросами теории и практики по отделению почвенных комков и камней от клубней занимались Ю. И. Зиновьев, В. Е. Зубков. Исследования рассмотрены в среде блокированного псевдоожиженного слоя и направлены на создание новых перспективных технологий, машин и их рабочих органов [2].

Анализ литературных источников свидетельствует о необходимости уточнения влияния состояния почвы на протекание технологического процесса.

Цели исследования: определить степень влияния состояния почвы на качественные показатели сепарации и возможностей различных типов сепарирующих устройств; определить направление дальнейшего изучения данного вопpoca.

Задачи исследования: рассмотреть объект сепарации, как сыпучий материал, изучить его физико-механические и технологические свойства, провести анализ работы сепарирующих устройств различных типов.

Материалы и методы исследования. Исследование проводилось на основе анализа роботы действующих сепарирующих систем, учитывая их технологические возможности.

Результаты исследования. Рассматривая корнеклубнеплоды (турнепс, брюква, морковь, свекла, картофель и др.), особое внимание следует уделить картофелю, так как это ценный и социально значимый продукт. Украина занимает четвертую позицию в мире по производству данной культуры. Это в первую очередь достигается большим количеством площадей посева, при низкой урожайности [5].

В связи с разнообразием почвенно-климатических условий на территории Украины и соответственно разным составом почвы необходимо предусматривать и использовать соответствующие агротехнологические операции по возделыванию корнеклубнеплодов. При этом учитывается возможность применения сортов различного назначения, схемы посадок, видов междурядий, комплексов машин и агрегатов.

Основной спецификой механизации уборки картофеля есть извлечение клубней картофеля из-под поверхности почвы. При этом рабочие 


\section{СТОРІНКА МОЛОДОГО ВЧЕНОГО}

органы воздействуют на почву, и соответственно их работа непосредственно зависит от физикомеханических свойств почвы [5]. На работу подкапывающих органов оказывают влияние параметры клубневого гнезда, на работу сепарирующих устройств - структура и состояние почвы и посторонних примесей.

Исходя из рекомендаций, почвы под картофель должны быть супесчаными, легко или среднесуглинистыми с содержанием гумуса 2-2,5 \% [7]. При этом не рекомендуется использование почв с тяжелым механическим составом и переувлажненных почв. Это в первую очередь объясняется снижением урожайности, повышенной степенью влияния болезней, а также создает трудности при отделении клубней от почвы и сторонних примесей. Поэтому, с целью избежать вышеуказанного, необходимо технологические операции подготовки почвы направить на разрушение комков и создания рыхлого состояния, которое следует обеспечивать вплоть до уборки.

Рассмотрим объект сепарации (смесь компонентов, которая поступает на устройства сепарации) как сыпучий материал. Сыпучие материалы принимают непосредственное участие во многих технологических процессах сельскохозяйственного производства. К ним относится основная часть растениеводства и корнеплоды. В нашем случае в качестве сыпучего материала есть смесь клубней картофеля и посторонних примесей, которые необходимо отделить (почва, растительные остатки, камни).

Для детального изучения технологического процесса сепарации необходимо проанализировать свойства и основные закономерности, которые происходят в сыпучих материалах. Так как во время сепарации происходит перемещение сыпучих материалов, то для проектирования технологичных процессов и рабочих органов соответствующих машин необходимо знать их физико-механические и технологические свойства.

Рассматривая твердую фазу сыпучего материала необходимо выделить основные группы: измеряемые, структурные, фрикционные, теплофизические, аэродинамические, электрофизические. Проведя анализ работы сепарирующих устройств, из этих групп следует выделить измеряемые, фрикционные и аэродинамические.

Охарактеризуем каждую из групп параметров твердой фазы сыпучего материала. Группа измеряемых определяет размерность и взаимосвязь частиц, а также их форму, что необходимо для проектирования сепарирующих устройств разделяющих по принципу размерности.

Рассматривая группу фрикционных свойств можно выделить силы трения спокойствия для частиц $d \geq 100$ мкм и статические и ударные силы отрыва частиц для $d \leq 100$ мкм. Эти параметры необходимы для конструирования сепарирующих устройств разделяющих материал по фрикционным и аэродинамическим свойствам.

Основным параметром сыпучего материала, как дисперсной однофазной системы есть плотность укладки, которая характеризуется соответствующим коэффициентом.

$$
K=\frac{V_{T}}{V}=\frac{\rho}{\gamma_{O}},
$$

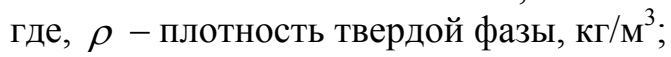

$\gamma_{O}$ - объемная плотность сыпучего материала, $\kappa \Gamma / \mathrm{M}^{3}$.

В механизации почв этот коэффициент принято называть коэффициентом пористости [4]. Этот коэффициент величина непостоянная и изменяется в зависимости от условий формирования сыпучего материала.

На процесс сепарации также будет влиять объемная плотность.

$$
\gamma_{O}=\frac{\rho}{K}
$$

Отсюда мы видим, что объемная плотность зависит от коэффициента укладки и соответственно также изменяется в зависимости от состояния сыпучего материала. Следовательно, отметим что тип, состояние и структурные составляющие почвы, непосредственно влияют на вышеуказанные параметры и соответственно на качественные показатели работы сепарирующих устройств. Рассматривая работу сепарирующих устройств различных типов в зависимости от состояния почвы необходимо рассмотреть их возможности. В основном работа сепарирующих органов основана на принципе разделения за счет разности отличительных свойств компонентов смеси, а именно: удельный вес, аэродинамические свойства, упругость, твердость, трения скольжения и качения, электрические свойства, способность поглощения лучей, оптическая отражательная способность, а также совокупность нескольких свойств [1]. Сепарация по удельному весу с использованием жидкости, «кипящего» слоя песка или мелкой почвы, требует дополнительных затрат и зависит от влажности почвы. Сепарация с использованием фрикционных свойств и разделяющих компоненты по различию коэффициентов трения скольжения и качения не может быть качественной и эффективной в случае работы уборочной машины на тяжелых или переувлажненных почвах. 


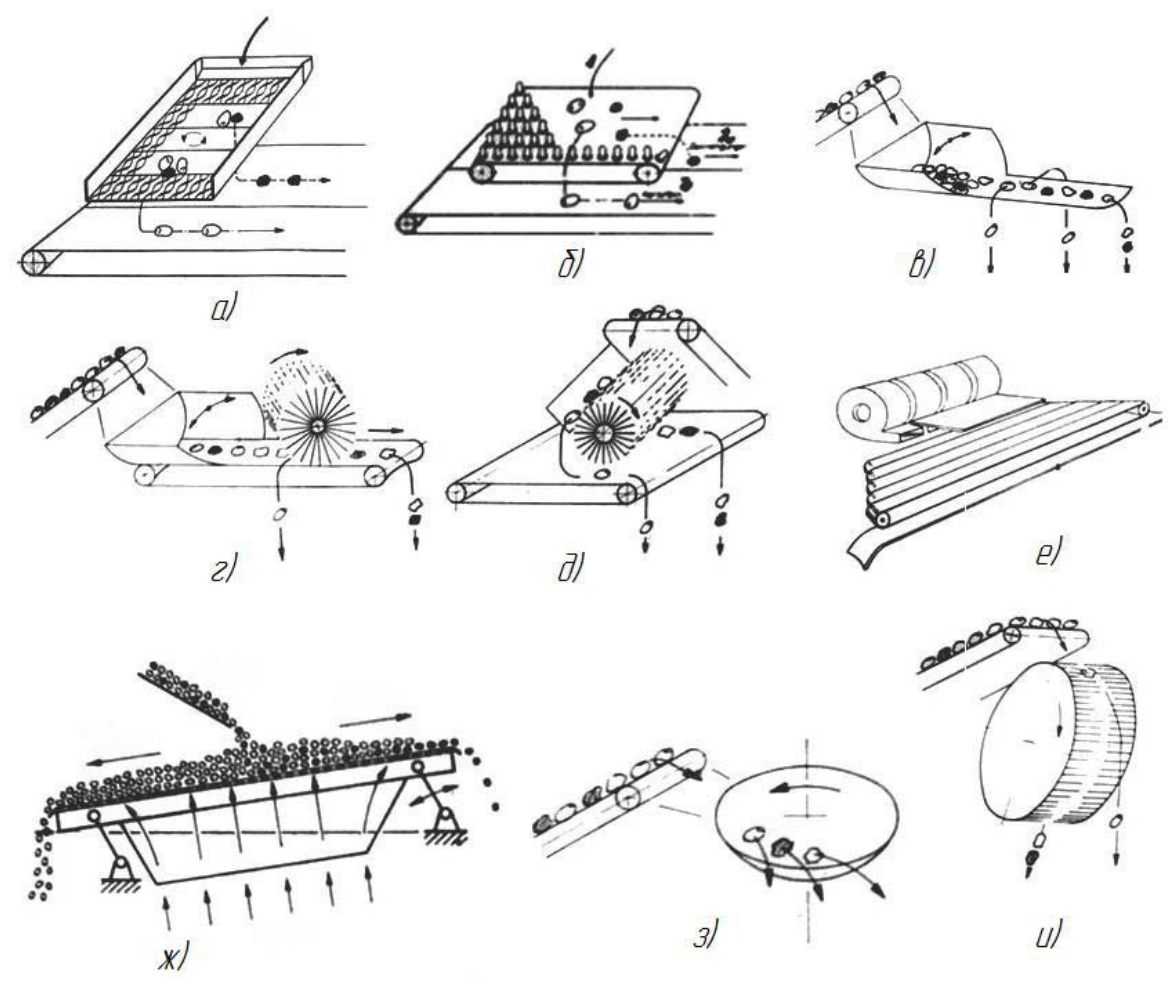

Рис. Рабочие органы для отделения клубней от комков и камней, основанные на комбинированном использовании ряда свойств: а) - обрезиненный грохот; б) - транспортер с резиновыми пальиами; в и г) - качающиеся желоба; д) - транспортер с вращающейся щеткой; е) - наклонный транспортер с вентилятором; ж) - вибрирующая поверхность; з) - конусный отделитель;

\section{и) - барабанные устройства}

Более эффективно сепарацию выполняют устройства, которые одновременно используют несколько отличительных свойств компонентов смеси [1].

Изучая работу сепарирующих устройств (см. рис.) проведем анализ и укажем их возможности.

При работе обрезиненного грохота (а) и разделяющего транспортера с резиновыми пальцами, наклоненными в сторону загрузки и движущимися поперек (б), разделение происходит в зависимости формы и абсолютного веса компонентов картофельного вороха.

Различие форм и шероховатости поверхности составляющих частей смеси используют устройства (в и г) - качающиеся желоба и (3) - конусные отделители.

Транспортер с вращающейся щеткой (д), а так же модификации этого устройства используют разность удельного веса, способность качения, масса и размеры тел.

Под действием силы, создаваемой потоком воздуха в наклонном транспортере с вентилятором (е), картофель, обладающий лучшей способностью качения, сдувается в сборные каналы, идущие параллельно столу, а камни отводятся столом.
Вибрирующая поверхность (ж) требует сортирования по крупности, так как разделение происходит в зависимости от удельного веса и абсолютного размера.

Работа барабанов с резиновыми лентами (и) и их модификаций основана на использование различия в весе и свойств поверхности разделяемых компонентов.

Работа рассмотренных сепарирующих устройств основана на использовании нескольких свойств сепарирующего материала и при определенных условиях могут выполнять сепарацию достаточно качественно. При этом в реальных условиях работы в (случаях работы на тяжелых почвах, почвы повышенной каменистости, влажности и др.) эти показатели снижаются вплоть до неприемлемых.

Выводы. Исходя из проведенного анализа объекта сепарации и возможностей сепарирующих устройств различных типов, можно определить дальнейшее направлении в изучении данного вопроса. При этом отмечается, что работоспособность сепарирующих устройств в большой степени зависит от состояния почвы. Наибольшее влияние на процесс сепарации оказывают механический состав и влажность почвы [8]. 
Поэтому в общем случае при проектировании и модернизации рабочих органов сепарирующих устройств необходимо учитывать коэффициент сепарации:

$$
\eta_{c}=\frac{m_{n}-m_{c x}}{m_{n}}, \%,
$$

\section{БИБЛИОГРАФИЯ}

1. Долгов И. А. Уборочные сельскохозяйственные машины (конструкция, теория, расчет) : учебник / И. А. Долгов. - Ростов-на-Дону : издательский центр ДГТУ, 2003. - 707 с.

2. Зиновьев Ю. И., Зубков В. Е. Научные основы механизированных процессов вторичной сепарации картофеля / Ю. И. Зиновьев, В. Е. Зубков. - Луганск : Лугань, 1997. - 176 с.

3. Колчин Н. Н. Техника для послеуборочной обработки и хранения картофеля: состояние и перспективы развития / Н. Н. Колчин // Картофель и овощи. - 2002. - №8. - С. 6-8.

4. Механіко-технологічні властивості сільськогосподарських матеріалів : підручник / [Царенко О. М., Войтюк Д. Г., Швайко В. М. та ін. ; за ред. Яцуна С. С.]. - К., 2003. - 448 с. где $\eta_{c}$ - коэффициент сепарации сыпучего материала, $m_{n}-$ масса вороха, который попадает на сепаратор, кг; $m_{n}-$ масса вороха который сходит с сепаратора, кг.

5. Наукові основи агропромислового виробництва в зоні Степу України / [редколегія : Зубець М. В. (голова) та ін.]. - К. : Аграрна наука, 2010. - $986 \mathrm{c}$.

6. Петров Г. Д. Картофелеуборочные машины. - М. : Машиностроение, 1984. - 320 с.

7. Современное промышленное производство овощей и картофеля с использованием систем капельного орошения / [Гиль Л. С. , Дьяченко В. И., Пашковский А. И., Сулима Л. Т.]. - Ж. : ЧП «Рута», 2010. - 390 c.

8. Трубилин Е. И. Машины для уборки сельскохозяйственных культур (конструкция, теория и расчет) : учебн. пос. - [2-е изд. перераб. и дополн.] / Трубилин Е. И. - КГАУ, Краснодар, $2010-325$ c. 